\title{
First-pass uptake and oxidation of glucose by the splanchnic tissue in young goats fed soy protein-based milk diets with or without amino acid supplementation
}

\author{
U. Schönhusen, ${ }^{* 1}$ P. Junghans, ${ }^{*}$ A. Flöter, ${ }^{*}$ J. Steinhoff-Wagner, ${ }^{*}$ S. Görs, ${ }^{*}$ F. Schneider,† C. C. Metges, ${ }^{*}$ \\ and H. M. Hammon* \\ *Department of Nutritional Physiology "Oskar Kellner," and \\ †Department of Reproductive Biology, Leibniz Institute for Farm Animal Biology (FBN), 18196 Dummerstorf, Germany
}

\begin{abstract}
The study was designed to examine whether feeding soy protein isolate as partial replacement of casein $(\mathrm{CN})$ affects glucose metabolism in young goats and whether effects may be ameliorated by supplementation of those AA known to be lower concentrated in soy than in CN. Goat kids (d 20 of age) were fed comparable milk protein diets, in which $50 \%$ of the crude protein was either CN (control, CON), soy protein isolate (SPI), or soy protein isolate supplemented with AA (SPIA) for $43 \mathrm{~d}$ ( $\mathrm{n}=8$ per group). On d 62 of age, a single bolus dose of $\mathrm{D}-\left[{ }^{13} \mathrm{C}_{6}\right]$ glucose $(10 \mathrm{mg} / \mathrm{kg}$ of BW) was given with the morning diet, and simultaneously, a single bolus dose of D- $\left[6,6-{ }^{2} \mathrm{H}_{2}\right]$ glucose $(5 \mathrm{mg} / \mathrm{kg}$ of BW) was injected into a jugular vein. Blood samples were collected between -30 and +420 min relative to the tracer administration to measure the ${ }^{13} \mathrm{C}$ and ${ }^{2} \mathrm{H}$ enrichments of plasma glucose and the ${ }^{13} \mathrm{C}$ enrichment of blood $\mathrm{CO}_{2}$. Glucose first-pass uptake by the splanchnic tissues was calculated from the rate of appearance of differentially labeled glucose tracer in plasma. Glucose oxidation was calculated from ${ }^{13} \mathrm{C}$ enrichment in blood $\mathrm{CO}_{2}$. In addition, plasma concentrations of triglycerides, nonesterified fatty acids, glucose, insulin, and glucagon were measured. On d 63 of age, kids were killed and jejunal mucosa and liver samples were collected to measure lactase mRNA levels and lactase and maltase activities in the jejunum and activities of pyruvate carboxylase and phosphoenolpyruvate carboxykinase (PEPCK) in the liver. Basal plasma glucose concentration tended to be higher in the CON than the SPIA group, whereas basal insulin was higher in the CON group than the SPI and SPIA groups, and glucagon was higher in the CON than the SPIA group. Plasma glucose and insulin concentrations increased during the first hour after feeding, whereas plasma glucagon increased immediately after feeding
\end{abstract}

Received July 12, 2012.

Accepted December 27, 2012

${ }^{1}$ Correspondence author: schoenhu@fbn-dummerstorf.de and after $1 \mathrm{~h}$ of feeding. First-pass uptake and glucose oxidation were not affected by diet. Maltase activities in proximal and mid jejunum and lactase activities in mid jejunum were lower in the CON than in the SPIA group. Activities of PEPCK were higher in the SPIA than in the SPI group. In conclusion, feeding milk diets with soy protein isolate seems to affect glucose status in kids, but has no effect on first-pass uptake and oxidation of glucose. The highest activities of lactase and maltase were observed after supplementation with AA. Higher PEPCK activities in the liver may point at elevated gluconeogenic activities after AA supplementation in soy-fed kids.

Key words: goat kid, soy protein, glucose first-pass uptake, stable isotope

\section{INTRODUCTION}

In preruminants, feeding soy protein instead of milk protein leads to alterations in the intestinal morphology, with consequences on the absorptive function (Seegraber and Morrill, 1986; Montagne et al., 1999). Studies by Lalles et al. (1995) in veal calves indicated that soy protein reduces the absorptive permeability of the small intestine to xylose. Boudry et al. (2003) demonstrated that soy protein impairs the sodium-dependent glucose absorption in the small intestine of piglet. However, supplementation of indispensable AA to soy protein partly avoided mucosal growth retardation (Schönhusen et al., 2010b) and increased the capacity of glucose uptake across the jejunal brush border membrane in the mid jejunum of goat kids (Giere, 2009). Recently, we found that Thr, Val, Ile, Leu, His, Lys, and Met supplemented to soy protein change jejunal proteins involved in processes related to cytoskeleton formation and energy metabolism in goat kids (Kuhla et al., 2007; Schönhusen et al., 2010b). Moreover, studies in lambs have shown that the glucose uptake along the small intestine is influenced by dietary AA and peptides via sodium-dependent glucose transporter1 activity; however, the regulatory action of dietary protein and its 
interaction with membrane transporters are not fully understood (Mabjeesh et al., 2003). It is conceivable that AA and peptides may provide some extra- or intracellular signals to activate the sodium-dependent glucose transporter1 protein. On the other hand, AA have been reported to increase the endogenous glucose production and utilization in growing lambs (AbdulRazzaq and Bickerstaffe, 1989). Both dietary AA and glucose are oxidative substrates and are used by the intestinal mucosa for energy generation (Windmueller and Spaeth, 1980). Dietary glucose oxidation by the intestine seems to become more important for providing energy in adaptation processes during which the intestinal digestive and absorptive function is stimulated (van der Schoor et al., 2001).

Due to alterations in the small intestinal morphology after soy protein feeding, we hypothesized that soy protein feeding may impair glucose metabolism, especially glucose first-pass uptake (FPU) and oxidation by the splanchnic tissues and endogenous glucose production, especially gluconeogenesis, in the liver. Amino acid supplementation to soy protein isolate may ameliorate these effects on systemic and hepatic glucose metabolism. The extent to which orally administered glucose is taken up by the intestine and metabolized within the splanchnic tissue (intestine and liver) or transported to the systemic circulation was determined by a dualstable-isotope-tracer technique (van der Schoor et al., 2004; Steinhoff-Wagner et al., 2011a).

\section{MATERIALS AND METHODS}

\section{Animals and Diets}

The experimental protocol was approved by the relevant authorities (Landesamt für Landwirtschaft, Lebensmittelsicherheit und Fischerei MecklenburgVorpommern, Germany; LALL M-V/TSD/7221.3-2.1017/05). Details on animals, housing, feeding, and the experimental protocol were as described by Schönhusen et al. (2010a). In brief, 24 male kids (German White dairy goat) were randomly assigned by age and BW to 3 treatment groups $(\mathrm{n}=8$ each). Dietary treatments started on d 20 of life for a period of $43 \mathrm{~d}$ (Montagne et al., 1999). All diets were based on skim milk powder $(28 \% \mathrm{CP}$ and $27 \%$ crude fat in DM; Table 1$)$. In the control group (CON) $50 \%$ of the milk protein was replaced by $\mathrm{CN}$ (1.3\% crude ash, $97.6 \% \mathrm{CP}$, and $1.1 \%$ crude fat in DM). In the soy group (SPI), $50 \%$ of the milk protein was replaced by soy protein isolate $(4.7 \%$ crude ash, $90.0 \% \mathrm{CP}$, and $2.5 \%$ crude fat in DM), whereas in the soy group with AA supplementation (SPIA) $50 \%$ of the milk protein was replaced by soy protein isolate, supplemented with those AA known to be at lower concentrations in soy protein isolate than in CN (Table 1). Diets were formulated to be isonitrogenous and isoenergetic. Lactose was added to provide a constant proportion of protein to $\mathrm{N}$-free extracts in all 3 diets. A DMI of $33 \mathrm{~g} /\left(\mathrm{kg}\right.$ of $\left.\mathrm{BW}^{0.75} \times \mathrm{d}\right)$ was provided, and energy and protein were supplied at 0.6 $\mathrm{MJ} /\left(\mathrm{kg}\right.$ of $\left.\mathrm{BW}^{0.75} \times \mathrm{d}\right)$ and $11 \mathrm{~g} /\left(\mathrm{kg}\right.$ of $\left.\mathrm{BW}^{0.75} \times \mathrm{d}\right)$, respectively. Diets were fed twice daily in equal parts by bottle. Kids were weighed weekly before the morning feeding, and DMI was adjusted for BW. Daily intake of DM, CP, and ME were not different among the groups. Kids of the CON, SPI, and SPIA groups did not differ with regard to initial and final BW. Details on feed intake, growth performance (mean ADG was $148 \pm 8$ $\mathrm{g} / \mathrm{d}$ ), and feed efficiency (mean feed efficiency was 786 $\pm 31 \mathrm{~g}$ of $\mathrm{ADG} / \mathrm{kg}$ of $\mathrm{DMI}$ ) were recently presented (Schönhusen et al., 2010a).

\section{Analytical Procedures}

Feed. Dry matter, crude ash, ether extract, and crude fat of the dried dietary components and experimental diets were determined according to the Weende standard procedure (Naumann and Bassler, 1993). Nitrogen was determined by combustion analysis (CNS-2000, Leco Corp., St. Joseph, MI) and CP was then calculated by multiplying the $\mathrm{N}$ content with 6.25 . The ME content of feed was calculated using digestible nutrients (Bezabih and Pfeffer, 2003). Digestible nutrients were calculated from the measured nutrient contents multiplied by the digestibility of nutrients using feedstuff tables (German Society of Nutrition Physiology, 2003). Lactose concentration was measured by the $\beta$-galactosidase method using a commercial kit (no. 10176303 035; R-Biopharm AG, Darmstadt, Germany). Lactose is hydrolyzed to D-glucose and D-galactose in the presence of $\beta$-galactosidase. D-Galactose is oxidized by NAD to D-galactonic acid in the presence of $\beta$-galactose dehydrogenase. The amount of NADH formed in reaction is stoichiometric to the amount of lactose. The increase in NADH is measured by light absorbance at 340 or $365 \mathrm{~nm}$. Dietary AA concentrations were measured by liquid ion-exchange chromatography (Hennig et al., 2004). Soy protein isolate was analyzed for the content of daidzein and genistein by HPLC after acid hydrolysis and extraction (Degen et al., 2002).

Blood. Blood samples were collected via a jugular vein catheter (Vasofix Certo; B. Braun Melsungen AG, Melsungen, Germany) in $\mathrm{K}_{3}$-EDTA containing Monovettes (Sarstedt AG \& Co., Nümbrecht, Germany; $1.8 \mathrm{~g} / \mathrm{L}$ of blood) on d 62 of life at 30 and $5 \mathrm{~min}$ before and at $5,10,15,20,30,40,60,90,120,180$, 260, 300, 360, and 420 min after the morning feeding to measure plasma concentrations of glucose, NEFA, 
Table 1. Ingredients and chemical composition of milk diets containing CN (control, CON) and soy protein isolate without (SPI) or supplemented with AA (SPIA) fed to kids

\begin{tabular}{lccc}
\hline & \multicolumn{3}{c}{ Diet $^{1}$} \\
\cline { 2 - 4 } Composition & CON & SPI & SPIA \\
\hline Ingredient, g/kg of DM & & & 587 \\
Skim milk powder $^{2}$ & 558 & - & - \\
CN $^{3}$ & 170 & 172 & 139 \\
Soy protein isolate $^{4}$ & - & 241 & 241 \\
Lactose monohydrate $_{\text {AA mixture }}^{5}$ & 242 & - & 35 \\
Chemical composition, g/kg of DM & & 329 & 329 \\
CP & 332 & 44 & 42 \\
Crude ash & 38 & 163 & 166 \\
Crude fat & 161 & 464 & 463 \\
Nitrogen-free extracts & 469 & 16.9 & 16.9 \\
ME, MJ/kg of DM & 16.9 & & \\
\hline CON = milk & & & \\
\hline
\end{tabular}

${ }^{1} \mathrm{CON}=$ milk diet containing acid-precipitated $\mathrm{CN}$ (50\% of total $\mathrm{CP}$ in the diet); $\mathrm{SPI}=$ milk diet containing soy protein isolate $(50 \%$ of total $\mathrm{CP}$ in the diet); SPIA = milk diet containing soy protein isolate supplemented with those AA known to be at lower concentrations in soy protein isolate than in CN (50\% of total CP in the diet).

${ }^{2}$ Skim milk powder, regular 26\% milk fat (DM basis; Nordmilch eG, Bremen, Germany).

${ }^{3}$ Acid-precipitated CN (Molkereigesellschaft Lauingen mbH, Lauingen, Germany).

${ }^{4}$ Soy protein isolate Supro-901 (Interfood Deutschland GmbH, Bad Nauheim, Germany); isoflavones content $(\mu \mathrm{g} / \mathrm{kg}$ of DM): daidzein, 516; genistein, 1,274.

${ }^{5}$ Composition (g/100 g of AA): L-Thr, 2; L-Ser, 4; L-Glu, 26; L-Val, 9; L-Ile, 4; L-Leu, 9; L-Tyr, 8; L-Phe, 1, LHis, 1; L-Lys, 9; L-Pro, 21; L-Met, 7; and L-Trp, 0.1 (Merck, Darmstadt, Germany).

and triglycerides, and at 5 min before and 10,20,30, $60,120,260$, and 420 min after the morning feeding to measure plasma concentrations of insulin and glucagon. Monovettes were placed on ice before centrifugation at $1,450 \times g\left(20 \mathrm{~min}\right.$ at $\left.4^{\circ} \mathrm{C}\right)$ to obtain blood plasma. Blood plasma was aliquoted and stored at $-20^{\circ} \mathrm{C}$ until analyzed.

Metabolites and Hormones. Plasma metabolites (glucose, NEFA, and triglycerides) were analyzed by the Landesanstalt für Landwirtschaft, Rostock, Germany, using the following kits: glucose (GOD-PAP kit LT-GL 0101, LT-SYS) and triglycerides (GPO-PAP kit LT-TR 0015, LT-SYS) from Labor + Technik Eberhard Lehmann GmbH (Berlin, Germany) and NEFA (FA 115) from Randox Laboratories GmbH (Krefeld, Germany). Analyses were performed using the automatic analyzer Cobas Mira Plus (Roche, Basel, Switzerland).

Hormone analyses were done by RIA using commercial kits from Linco (Linco Research Inc., St. Charles, $\mathrm{MO})$. Plasma insulin concentrations were analyzed using the sensitive rat insulin kit (SRI-13K) with purified human insulin as standard (0.1 to $0.2 \mathrm{ng} / \mathrm{mL}$ ), the primary antibody raised in guinea pigs, and a goat anti-guinea pig IgG for the bound/free separation. Glucagon concentrations were measured using the glucagon kit (GL-32K), which was specific for pancreatic glucagon. The antibody used in this assay shows high cross-reactivity with bovine glucagon (Hammon et al., 2009). The limit of detection was $20 \mathrm{pg} / \mathrm{mL}(100-\mu \mathrm{L}$ sample size).
Glucose $\boldsymbol{F P U}$. For determination of glucose FPU [i.e., glucose utilization by the splanchnic tissues (intestine and liver) when orally administrated glucose passes the splanchnic tissues for the first time], an oral bolus dose of $\mathrm{D}^{-}\left[{ }^{13} \mathrm{C}_{6}\right]$ glucose $(10 \mathrm{mg} / \mathrm{kg}$ of $\mathrm{BW}, 99$ atom\% ${ }^{13} \mathrm{C}$; Campro Scientific GmbH, Berlin, Germany; $\mathrm{n}=$ 6 per group), was fed with half of the daily diet on d 62 of life. Simultaneously, D- $\left[6,6-{ }^{2} \mathrm{H}_{2}\right]$ glucose $(5 \mathrm{mg} /$ $\mathrm{kg}$ of BW, 99 atom $\%{ }^{2} \mathrm{H}$; Campro Scientific GmbH; n $=6$ per group) was injected as an intravenous bolus into a jugular vein. To obtain baseline data, the same amount of unlabeled D-glucose (glucose monohydrate; Merck, Darmstadt, Germany) was administrated both orally und intravenously to 2 kids of each group. Blood samples were taken via jugular vein catheter in $\mathrm{Li}$ heparinized Monovettes (Sarstedt AG \& Co.; 14-15 $\mathrm{kIU} / \mathrm{L}$ of blood) at 30 and $5 \mathrm{~min}$ before and at 5,10 , $15,20,30,40,60,90,120,180,260,300,360$, and 420 min after tracer application to measure the ${ }^{13} \mathrm{C}$ and ${ }^{2} \mathrm{H}$ enrichments of plasma glucose and the ${ }^{13} \mathrm{C}$ enrichment of blood $\mathrm{CO}_{2}$ (Junghans et al., 2007; 2010). Plasma and whole blood were kept at $-20^{\circ} \mathrm{C}$ until analyzed.

Plasma ${ }^{13} \mathrm{C}$ and ${ }^{2} \mathrm{H}$ enrichments of $\mathrm{D}-\left[{ }^{13} \mathrm{C}_{6}\right]-$ and $\mathrm{D}$ $\left[6,6-{ }^{2} \mathrm{H}_{2}\right]$ glucose were measured as aldonitrile pentaacetate derivative (Pfaffenberger et al., 1975) by means of GC-MS (GCMS QP 2010, coupled with GC 2010; Shimadzu GmbH, Duisburg, Germany), with exception of the ion fragment $m / z 330$ for $\mathrm{D}-\left[6,6-{ }^{2} \mathrm{H}_{2}\right]$ glucose that were monitored to calculate the enrichments of D- $\left[6,6-{ }^{2} \mathrm{H}_{2}\right]$ glucose as mole percent excess (MPE). To 
correct enrichments of $\mathrm{D}-\left[{ }^{13} \mathrm{C}_{6}\right]$ glucose and $\mathrm{D}-\left[6,6-{ }^{2} \mathrm{H}_{2}\right]$ glucose calibration curves derived from known standard mixtures of $\mathrm{D}-\left[{ }^{13} \mathrm{C}_{6}\right]$ glucose and $\mathrm{D}-\left[6,6-{ }^{2} \mathrm{H}_{2}\right]$ glucose with unlabeled glucose (0 to $5 \mathrm{MPE}$ ) were generated (Junghans et al., 2010).

Plasma D- $\left[6,6-{ }^{2} \mathrm{H}_{2}\right]$ glucose enrichments were used to calculate the rate of appearance of glucose $\left(\mathbf{R a}_{\mathbf{i v}}\right)$ as follows (Junghans et al., 2007): $\mathrm{Ra}_{\mathrm{iv}}=\mathrm{D} / \mathrm{A}\left({ }^{2} \mathrm{H}\right)$, where $\mathrm{D}$ is dose of $\mathrm{D}-\left[6,6-{ }^{2} \mathrm{H}_{2}\right]$ glucose tracer i.v. injected $(\mu \mathrm{mol} / \mathrm{kg}$ of $\mathrm{BW})$ and $\mathrm{A}\left({ }^{2} \mathrm{H}\right)$ is the area under the $\mathrm{D}-$ $\left[6,6-{ }^{2} \mathrm{H}_{2}\right]$ glucose enrichment-time curve (MPE $\times$ min). In the same way, the plasma rate of appearance of $\left[{ }^{13} \mathrm{C}_{6}\right]$ glucose from oral tracer administration $\left(\mathbf{R a}_{\text {oral }}\right)$ was calculated using the oral $\mathrm{D}-\left[{ }^{13} \mathrm{C}_{6}\right]$ glucose tracer administered $(\mu \mathrm{mol} / \mathrm{kg}$ of $\mathrm{BW})$ and the area under the $\mathrm{D}-\left[{ }^{13} \mathrm{C}_{6}\right]$ glucose enrichment-time curve $(\mathrm{MPE} \times \min )$ as described (Junghans et al., 2007). Plasma kinetics of the isotopomeres containing ${ }^{2} \mathrm{H}$ and ${ }^{13} \mathrm{C}$ were evaluated by the SAAM II software (Barrett et al., 1998). To fit kinetics of isotopic enrichments, we applied the sum of 3 exponentials for ${ }^{13} \mathrm{C}$ enrichments and of 2 exponentials for ${ }^{2} \mathrm{H}$ enrichments.

The splanchnic extraction of the oral tracer was calculated as FPU $[\mu \mathrm{mol} /(\min \times \mathrm{kg})]$ :

$$
\mathrm{FPU}=\left(\mathrm{Ra}_{\text {oral }}-\mathrm{Ra}_{\mathrm{iv}}\right) / \mathrm{Ra}_{\text {oral }} \times \text { glucose intake },
$$

where glucose intake is expressed in $\mu \mathrm{mol} /(\mathrm{min} \times \mathrm{kg}$ of BW). The fractional FPU (fFPU) was expressed as a percentage of dietary glucose intake:

$$
\mathrm{fFPU}=\left(\mathrm{Ra}_{\text {oral }}-\mathrm{Ra}_{\mathrm{iv}}\right) / \mathrm{Ra}_{\text {oral }} \times 100
$$

as described (van der Schoor et al., 2004).

The ${ }^{13} \mathrm{C}$ enrichment in blood $\mathrm{CO}_{2}$ derived from oxidation of $\mathrm{D}-\left[{ }^{13} \mathrm{C}_{6}\right]$ glucose was measured as recently described (Junghans et al., 2007). The calculation of ${ }^{13} \mathrm{C}$ recovery $\left({ }^{13} \mathbf{C}\right.$ REC $)$ in blood $\mathrm{CO}_{2}\left(\%\right.$ of ${ }^{13} \mathrm{C}$ dose $)$ is based on an approximate $\mathrm{CO}_{2}$ production of $1 \mathrm{mmol} /$ $\left(\min \times \mathrm{kg}\right.$ of $\left.\mathrm{BW}^{0.75}\right)$ taken from previous studies in goat kids, which included a potential error for calculation of about 10\% (Junghans et al., 1997).

Tissues. Kids were slaughtered on d 63 of life at $5 \mathrm{~h}$ after morning feeding. The abdominal cavity was immediately opened and the liver and jejunum were removed. The jejunum was divided into 3 equal segments (proximal, medial, and distal), which were rinsed with ice-cold saline $(0.9 \% \mathrm{NaCl}$, wt/vol). Mucosal tissue was harvested by scraping the respective jejunal segments with a glass slide. Liver samples and mucosa tissue were snap frozen in liquid $\mathrm{N}$ and stored at $-80^{\circ} \mathrm{C}$ for later analyses. Prior to analysis tissue was homogenized under liquid nitrogen. Protein content in liver and mu- cosa tissue was determined by the method of Bradford (Bradford, 1976).

Analyses in the Jejunum. For mRNA measurements of lactase, total RNA was extracted from jejunal mucosa using TRIzol reagent (Invitrogen GmbH, Karlsruhe, Germany), and resuspended in RNase-free water (treated with diethyl pyrocarbonate; Sigma-Aldrich, Deisendorf, Germany). The integrity and purity of RNA were ensured by measurement of optical density [OD; ratio of OD at $260 \mathrm{~nm}$ to $\mathrm{OD}$ at $280 \mathrm{~nm}\left(\mathrm{OD}_{260} /\right.$ $\left.\mathrm{OD}_{280}\right)>1.9$ ] and gel electrophoresis using ethidium bromide staining. The RNA was quantified by $\mathrm{OD}_{260}$ measurement. A total of $1 \mu \mathrm{g}$ of RNA was reverse transcribed into cDNA using random primers (Random Primers; Invitrogen $\mathrm{GmbH}$ ) and purified using a High Pure PCR Product Purification Kit (Roche Diagnostics GmbH, Mannheim, Germany; Hammon et al., 2009). Quantitative gene expression was determined by the Light Cycler Real-Time PCR System (Roche Applied Science, Mannheim, Germany), using SYBR Green I as detection format. Glyceraldehyde 3-phosphate dehydrogenase was used as a reference gene because it was not different expressed in the samples. Primers from bovine species were used for lactase and GAPDH mRNA measurement (Ontsouka et al., 2004; Hammon et al., 2009). Melting temperatures were checked for specificity of each product. Additionally gel electrophoresis of the PCR product demonstrated only 1 single band at the expected size. Products were verified by sequencing using an ABI sequencing kit (ABI Big Dye Terminator; Applied Biosystems, Darmstadt, Germany) and an ABI 310 Genetic Analyzer (Applied Biosystems). Values of crossing point $(\mathbf{C t})$ for lactase and for GAPDH were corrected for different runs by an internal standard $(\Delta \mathrm{Ct})$. For lactase samples, $\Delta \mathrm{Ct}_{\mathrm{GAPDH}}$ was used for normalization by subtractions $\left(\Delta \Delta \mathrm{Ct}=\Delta \mathrm{Ct}_{\text {lactase }}\right.$ - $\Delta \mathrm{Ct}_{\mathrm{GAPDH}}$; Hammon et al., 2003). Efficiency of PCR was $>1.8$ and inter- and intraassay coefficients for reverse-transcription PCR of lactase and GAPDH genes were $<1 \%$.

Activities of lactase (EC 3.2.1.23) and maltase (EC 3.2.1.20) were determined by incubating the mucosa homogenates with lactose and maltose (Mir et al., 1997). Galactose and glucose produced in incubation media were measured with the use of kits: lactose/Dgalactose (no. 0176 303) and D-glucose (no. 0716 251) from R-Biopharm AG, and enzyme activity of tissue homogenate was reported as $\mu \mathrm{mol}$ of substrate hydrolyzed per 30 min per milligram of protein.

Analyses in the Liver. Measurements of hepatic phosphoenolpyruvate carboxykinase (PEPCK; EC 4.1.1.32) and pyruvate carboxylase (PC; EC 6.4.1.1) was recently described (Steinhoff-Wagner et al., 2011a). 
The PEPCK activities were determined in cell homogenates of liver by measuring the carboxylation of phosphoenolpyruvate to oxaloacetate using $\mathrm{NaH}^{14} \mathrm{CO}_{3}$ with the addition of $\mathrm{NADH}$ and malate dehydrogenase to ensure the conversation of the reaction product, oxaloacetate, to malate (Atkin et al., 1979). Activities of PC were assayed in crude homogenates by $\mathrm{NaH}^{14} \mathrm{CO}_{3}$ incorporation into oxaloacetate and citrate in the presence of pyruvate (Atkin et al., 1979).

\section{Statistical Analyses}

Statistical evaluation was performed with SAS for Windows (release 9.1.3; SAS Institute, 2004). Data are expressed as means \pm standard error of the mean. For the detection of differences among the jejunal segments and the diets a 2 factorial variance analysis model was not suitable, because estimations of variance for one factor (jejunal segment) showed great differences for almost all parameters. Therefore, differences between the diets shown for enzyme activity and mRNA concentration in the jejunum were analyzed based on a one-factor (diet) model using PROC GLM and were localized by the Tukey $t$-test. Differences among jejunal segments without consideration of feeding groups were analyzed by paired $t$-test of the PROC TTEST. Group differences of glucose FPU, ${ }^{13} \mathrm{C}$ REC in blood $\mathrm{CO}_{2}$, and enzyme activities in liver were analyzed by PROC GLM, and differences were localized by the Tukey $t$-test. Differences between feeding groups with $P<0.1$ were defined as a trend and with $P<0.05$ as significant.

Diet and time effects on plasma concentration of metabolites and hormones were assessed by using the random and repeated methods of PROC MIXED of SAS. The effect of diet, time, or their interaction was considered fixed and goat was considered random. Differences were identified by Tukey $t$-test as described above.

\section{RESULTS}

\section{Plasma Metabolites and Hormone Concentrations}

Before feed intake, plasma glucose concentrations tended to be higher $(P<0.1)$ in the CON than in the SPIA group, but plasma concentrations of NEFA and triglycerides were not affected by diet (Figure 1). Plasma insulin concentrations before feed intake were higher $(P<0.05)$ in the CON group than in SPI and SPIA groups, and glucagon concentrations were higher in the CON group than in the SPIA group (Figure 2).

Plasma glucose concentrations increased $(P<0.001)$ during the first $60 \mathrm{~min}$ after feed intake and showed a diet $\times$ time interaction $(P<0.05)$. Plasma NEFA concentrations decreased $(P<0.001)$ immediately after feed intake and increased $(P<0.001)$ from 60 min onward. Postprandial plasma NEFA concentrations tended to be higher $(P<0.1)$ in the SPI group than in the CON group. Plasma triglyceride concentrations decreased $(P<0.001)$ shortly after feed intake and increased $(P<0.001)$ from $40 \mathrm{~min}$ onward, and showed a diet $\times$ time interaction $(P<0.05$; Figure 1$)$. Plasma insulin concentrations increased $(P<0.001)$ during the first $60 \mathrm{~min}$ after feeding, but did not differ after feeding among diets. Glucagon concentrations increased $(P<0.001)$ immediately after feed intake and again $60 \mathrm{~min}$ after feeding and tended to be lower $(P=0.1)$ in the SPIA group than in the CON group. The glucagon-to-insulin ratio decreased up to $1 \mathrm{~h}$ after feed intake, increased thereafter, but was not different between groups (Figure 2).

\section{Glucose FPU}

After oral $\left[{ }^{13} \mathrm{C}_{6}\right]$-glucose administration, the plasma appearance rate of $\left[{ }^{13} \mathrm{C}_{6}\right]$ glucose showed no diet effect. Likewise, after intravenous $\left[6,6-{ }^{2} \mathrm{H}_{2}\right]$ glucose injection, the plasma appearance rate of $\left[6,6-{ }^{2} \mathrm{H}_{2}\right]$ glucose was not different among diets. The absolute FPU and the fFPU did not differ among diets. The cumulative ${ }^{13} \mathrm{C}$ REC rate in blood $\mathrm{CO}_{2}$ at 420 min after oral ingestion of $\left[{ }^{13} \mathrm{C}_{6}\right]$ glucose was not affected by diet (Table 2 ).

\section{Enzyme mRNA Concentrations and Activities in the Jejunum}

Lactase mRNA levels in mucosa of the proximal and medial jejunum showed no diet effects, but mRNA concentrations of lactase were higher $(P<0.01)$ in the proximal than in medial jejunum. Activities of mucosal lactase in the proximal and distal jejunum did not differ among diets, whereas in the medial jejunal mucosa, lactase activities were lower $(P<0.01)$ in the CON group than in the SPIA group. Mucosal activities of maltase in the proximal and medial jejunum were lower $(P<0.05)$ in the CON group than in the SPIA group, but no diet effects on maltase activity were observed in the distal jejunum. Lactase activities were lowest $(P<$ $0.01)$ and maltase activities were higher $(P<0.01)$ in the distal jejunum (Table 3).

\section{Gluconeogenic Enzyme Activities in Liver}

Activities of PEPCK tended to be lower $(P<0.1)$ in the CON group than in the SPIA group, and were lower $(P<0.01)$ in the SPI group than in the SPIA group. Activities of PC showed no diet effects (Figure 3). 
A

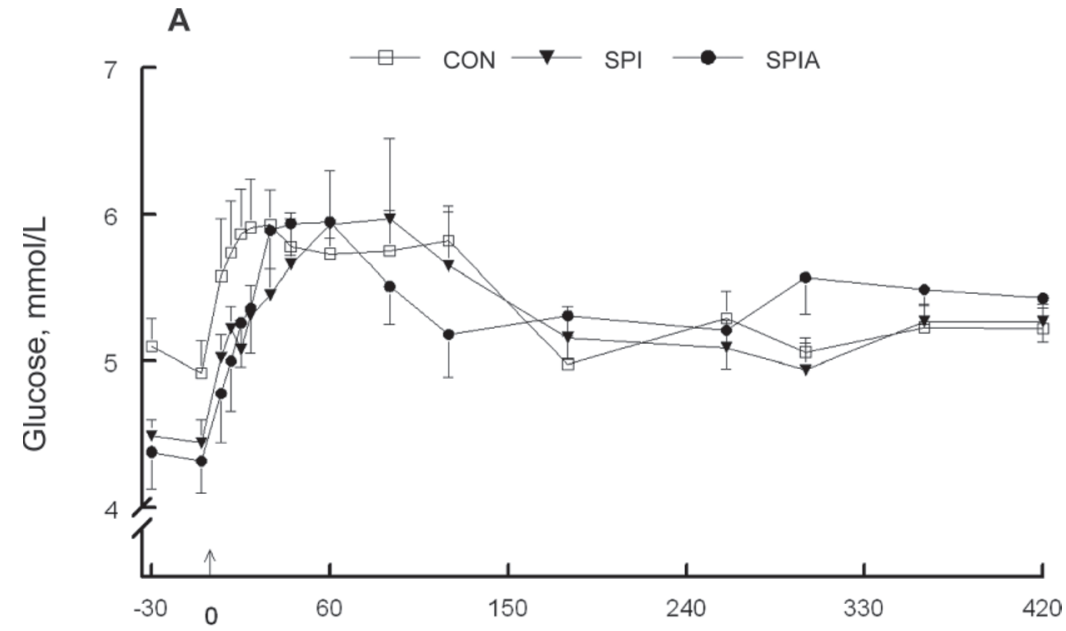

B

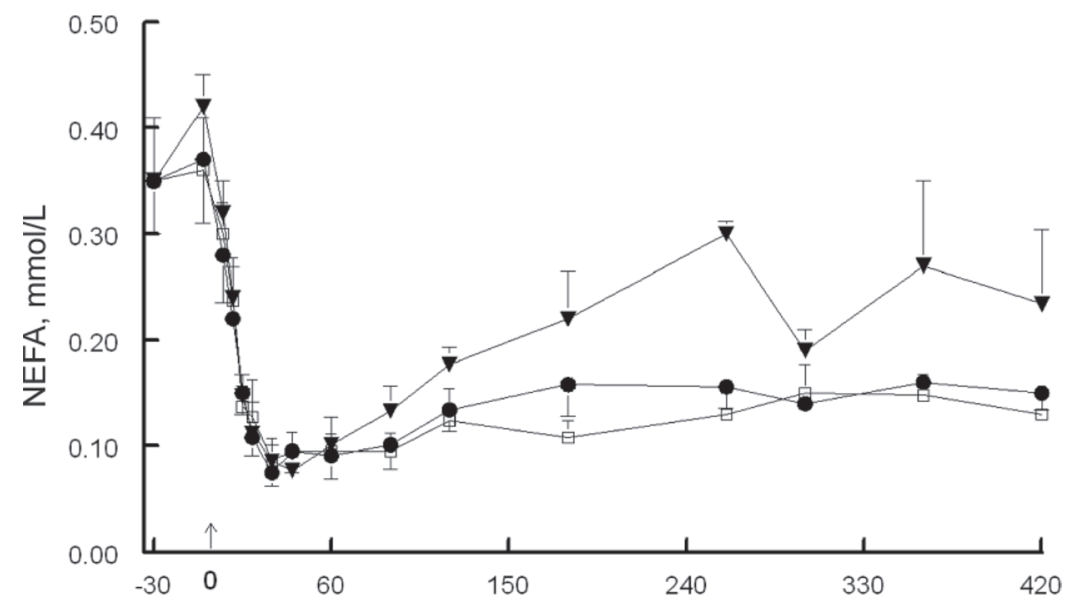

C

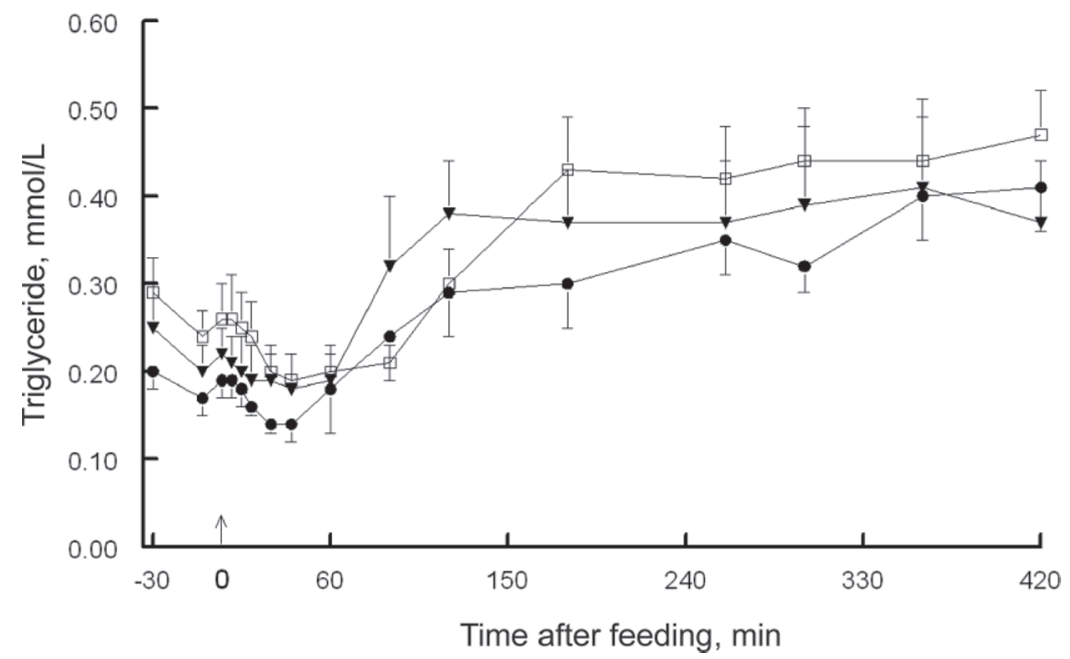

Figure 1. Plasma concentrations of glucose (A), NEFA (B), and triglycerides (C) before and after morning feeding in goat kids fed milkbased diets containing CN (control, CON; $\square$ ) or soy protein isolate without (SPI; $\mathbf{\nabla}$ ) or with AA supplementation (SPIA; $\bullet$ ). Values are means \pm SEM ( $\mathrm{n}=8$ per group). Fixed effects ( $P$-value) for glucose concentrations: diet $<0.1$ (before feed intake), time $<0.001$ (pre- and postprandial), diet $\times$ time $<0.05$ (pre- and postprandial); for NEFA concentrations (pre- and postprandial): diet $<0.1$, time $<0.001$; for triglyceride concentration (pre- and postprandial): time $<0.001$, diet $\times$ time $<0.05$. 
SCHÖNHUSEN ET AL.

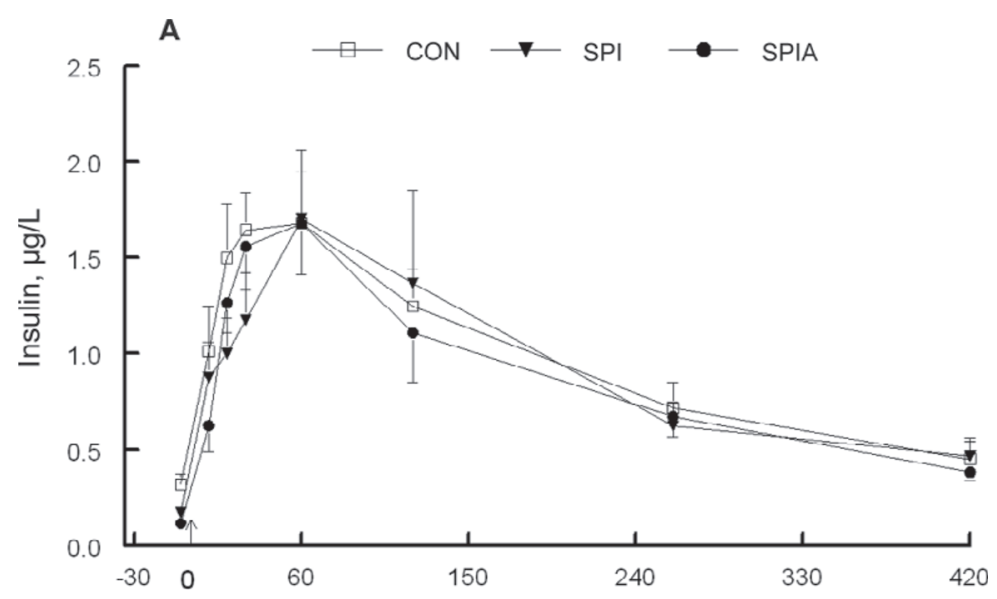

B
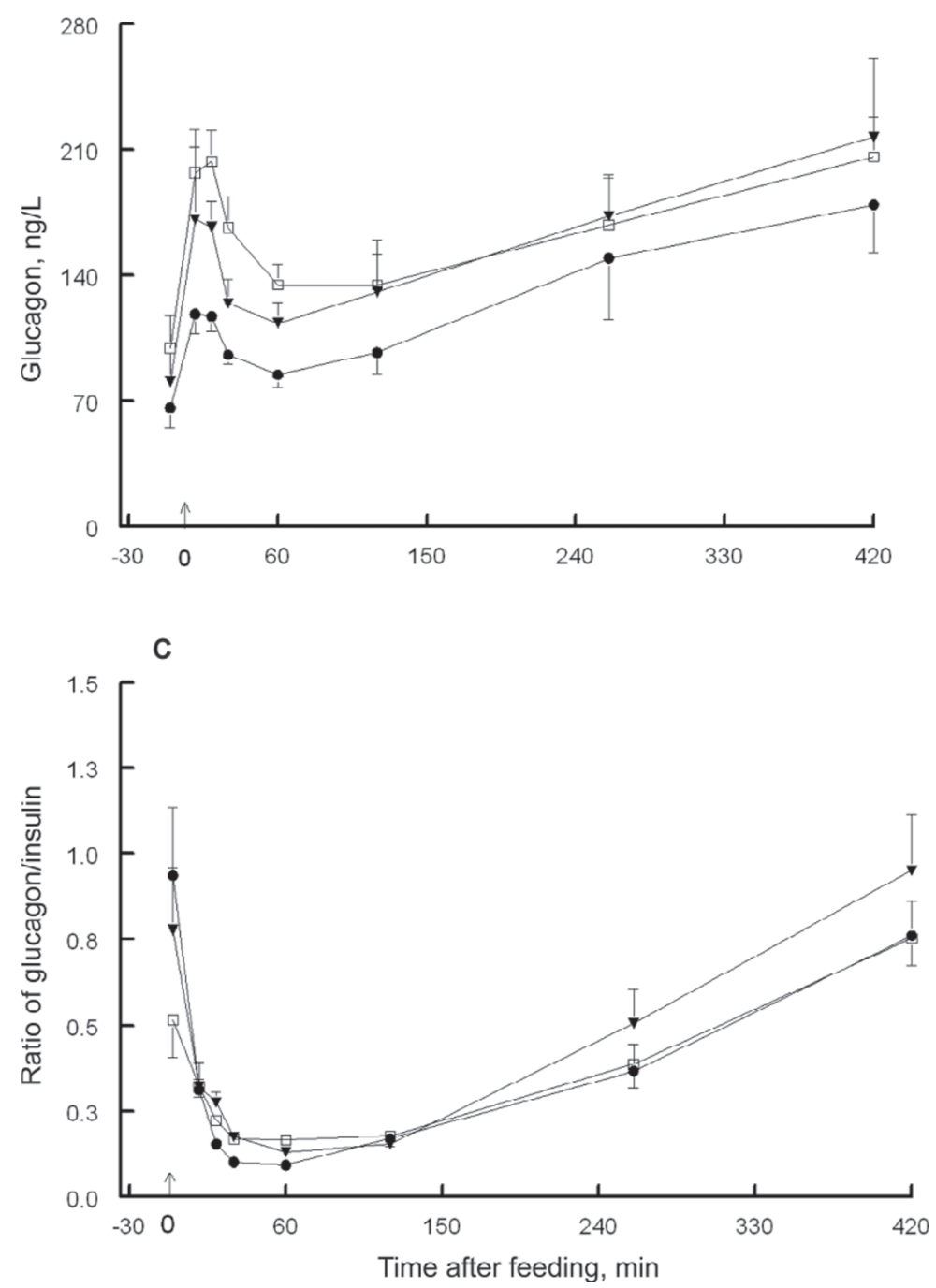

Figure 2. Plasma concentrations of insulin (A), glucagon (B) and ratio of glucagon to insulin (C) before and after morning feeding in goats kids fed milk-based diets containing CN (control, CON; $\square$ ) or soy protein isolate without (SPI; $\mathbf{v}$ ) or with AA supplementation (SPIA; $\bullet$ ). Values are means \pm SEM $(\mathrm{n}=8$ per group). Fixed effects $(P$-value) for insulin concentration: diet $<0.05$ (before feed intake), time $<0.001$ (pre- and postprandial); for glucagon concentration: diet $<0.05$ (before feed intake), time $<0.001$ (pre- and postprandial); for glucagon-to-insulin ratio: time $<0.001$ (pre- and postprandial). 
Table 2. Plasma rate of appearance of $\left[\mathrm{U}_{-}{ }^{13} \mathrm{C}\right]$ glucose $\left(\mathrm{Ra}_{\text {oral }}\right)$ and $\left[6,6{ }^{2} \mathrm{H}_{2}\right]$ glucose $\left(\mathrm{Ra}_{\mathrm{iv}}\right)$, glucose first-pass uptake (FPU) and fractional FPU (fFPU), and ${ }^{13} \mathrm{C}$ recovery rate in blood $\mathrm{CO}_{2}\left({ }^{13} \mathrm{C}\right.$ REC) in kids fed milk diets containing CN (control, CON) or soy protein isolate without (SPI) or supplemented with AA (SPIA)

\begin{tabular}{|c|c|c|c|c|c|}
\hline \multirow[b]{2}{*}{ Item } & \multicolumn{3}{|c|}{ Diet $^{1}$} & \multirow[b]{2}{*}{$\mathrm{SEM}^{2}$} & \multirow[b]{2}{*}{$P$-value ${ }^{3}$} \\
\hline & $\mathrm{CON}$ & SPI & SPIA & & \\
\hline $\begin{array}{l}\mathrm{Ra}_{\text {oral }}{ }^{4} \mu \mathrm{mol}(\min \times \mathrm{kg}) \\
\mathrm{Ra}_{\mathrm{iv},}{ }^{5} \mu \mathrm{mol}(\min \times \mathrm{kg}) \\
\mathrm{FPU}, \mu \mathrm{mol} /(\min \times \mathrm{kg}) \\
\mathrm{fFPU}, \% \text { of dose } \\
{ }^{13} \mathrm{C} \mathrm{REC},{ }^{6} \% \text { of dose }\end{array}$ & $\begin{array}{l}80.9 \\
46.3 \\
17.3 \\
37.8 \\
51.4\end{array}$ & $\begin{array}{l}65.8 \\
43.4 \\
11.4 \\
32.4 \\
49.3\end{array}$ & $\begin{array}{l}85.9 \\
40.9 \\
21.8 \\
47.4 \\
49.6\end{array}$ & $\begin{array}{r}14.6 \\
4.8 \\
5.8 \\
11.9 \\
2.0\end{array}$ & $\begin{array}{l}0.6 \\
0.8 \\
0.5 \\
0.4 \\
0.7\end{array}$ \\
\hline \multicolumn{6}{|c|}{$\begin{array}{l}{ }^{1} \mathrm{CON}=\text { milk diet containing acid-precipitated } \mathrm{CN}(50 \% \text { of total } \mathrm{CP} \text { in the diet }) \text {; SPI }=\text { milk diet containing } \\
\text { soy protein isolate }(50 \% \text { of total } \mathrm{CP} \text { in the diet }) \text { S SPIA }=\text { milk diet containing soy protein isolate supplemented } \\
\text { with AA }(50 \% \text { of total } \mathrm{CP} \text { in the diet). Values are means }(\mathrm{n}=6) . \\
{ }^{2} \text { Pooled SEM. } \\
{ }^{3} \mathrm{Main} \text { effect of diet. } \\
{ }^{4} \mathrm{After} \text { oral }\left[\mathrm{U}^{13} \mathrm{C}\right] \text { glucose administration. } \\
{ }^{5} \mathrm{After} \text { intravenous }\left[6,6-{ }^{2} \mathrm{H}_{2}\right] \text { glucose injection. } \\
{ }^{6} \mathrm{Cumulative} \text { over a period of } 420 \text { min. Calculation of }{ }^{13} \mathrm{C} \text { recovery is based on a } \mathrm{CO}_{2} \text { production of } 1 \mathrm{mmol} / \\
\left(\mathrm{min} \times \mathrm{kg} \text { BW }{ }^{0.75}\right) \text {. }\end{array}$} \\
\hline
\end{tabular}

\section{DISCUSSION}

\section{Dietary Effects on Jejunal Enzyme Activities}

Changes in the development of enterocytes and in the structure of villi determine the digestive and absorptive capacity of the small intestine (Tivey and Smith, 1989). The length of villi and mucosal disaccharidase activities in enterocytes are an important factor for nutrient absorption (Mir et al., 1997). In spite of reduced villus height in the SPI group after soy feeding (Schönhusen et al., 2010a,b), we did not observe any appreciable differences in the activities of lactase and maltase in jejunal mucosa between the CON and SPI groups. This was also the case for lactase mRNA abundance in the intestine. In general, a reduction of jejunal disaccharidase activities is often, but not invariably associated with reduced villus height (Langman and Rowland, 1990; Montagne et al., 1999). Although villus size was negatively affected in these goats after soy protein feeding (Schönhusen et al., 2010a), carbohydrate digestion on the cellular level was obviously not impaired after soy protein feeding. Nevertheless, glucose absorption was probably reduced in SPI goats due to reduced villus size of the small intestine and reduced glucose transport capacity in SPI goats (Giere, 2009; Schönhusen et al., 2010a).

Lactase and maltase activities were highest in goats fed soy protein supplemented with AA. Consistent with recent morphometric measurements, a trend for a stimulating effect of AA supplemented to soy protein isolate on mucosal growth in the mid to distal jejunum is indicated (Schönhusen et al., 2010a,b). This region,

Table 3. Expression of lactase mRNA and enzyme activities of lactase and maltase in jejunum of kids fed milk diets containing CN (control, CON) or soy protein isolate without (SPI) or supplemented with AA (SPIA)

\begin{tabular}{|c|c|c|c|c|c|c|}
\hline \multirow[b]{2}{*}{ Item } & \multirow[b]{2}{*}{ Site $^{1}$} & \multicolumn{3}{|c|}{ Diet $^{2}$} & \multirow[b]{2}{*}{$\mathrm{SEM}^{3}$} & \multirow[b]{2}{*}{$P$-value ${ }^{4}$} \\
\hline & & $\mathrm{CON}$ & SPI & SPIA & & \\
\hline \multirow[t]{2}{*}{ Lactase mRNA concentrations, relative to GADPH } & $\mathrm{p}$ & 25.7 & 13.2 & 31.2 & 5.2 & 0.2 \\
\hline & $\mathrm{m}$ & 11.7 & 8.7 & 12.7 & 2.7 & 0.6 \\
\hline \multirow[t]{3}{*}{ Lactase activity, $\mu \mathrm{mol}$ of lactose hydrolyzed/(mg of protein $\times 30 \mathrm{~min})$} & $\mathrm{p}$ & 2.7 & 2.4 & 2.8 & 0.4 & 0.7 \\
\hline & $\mathrm{m}$ & $1.3^{\mathrm{b}}$ & $2.0^{\mathrm{ab}}$ & $3.0^{\mathrm{a}}$ & 0.4 & 0.01 \\
\hline & $\mathrm{d}$ & 0.3 & 0.5 & 0.9 & 0.2 & 0.12 \\
\hline \multirow[t]{3}{*}{ Maltase activity, $\mu \mathrm{mol}$ of maltose hydrolyzed $/(\mathrm{mg}$ of protein $\times 30 \mathrm{~min})$} & $\mathrm{p}$ & $1.8^{\mathrm{b}}$ & $1.9^{\mathrm{ab}}$ & $2.2^{\mathrm{a}}$ & 0.1 & 0.03 \\
\hline & $\mathrm{m}$ & $2.3^{\mathrm{b}}$ & $2.9^{\mathrm{ab}}$ & $3.4^{\mathrm{a}}$ & 0.2 & 0.02 \\
\hline & d & 4.1 & 5.5 & 6.6 & 0.7 & 0.15 \\
\hline
\end{tabular}

${ }^{\mathrm{a}, \mathrm{b}}$ Means within a row with different superscripts differ $(P<0.05)$.

${ }^{1}$ Jejunal site: $\mathrm{p}=$ proximal; $\mathrm{m}=$ medial; $\mathrm{d}=$ distal.

${ }^{2} \mathrm{CON}=$ milk diet containing acid-precipitated $\mathrm{CN}$ (50\% of total $\mathrm{CP}$ in the diet); SPI = milk diet containing soy protein isolate $(50 \%$ of total $\mathrm{CP}$ in the diet); SPIA = milk diet containing soy protein isolate supplemented with AA ( $50 \%$ of total $\mathrm{CP}$ in the diet). Values are means $(\mathrm{n}=8)$.

${ }^{3}$ Pooled SEM.

${ }^{4}$ Main effect of diet. 


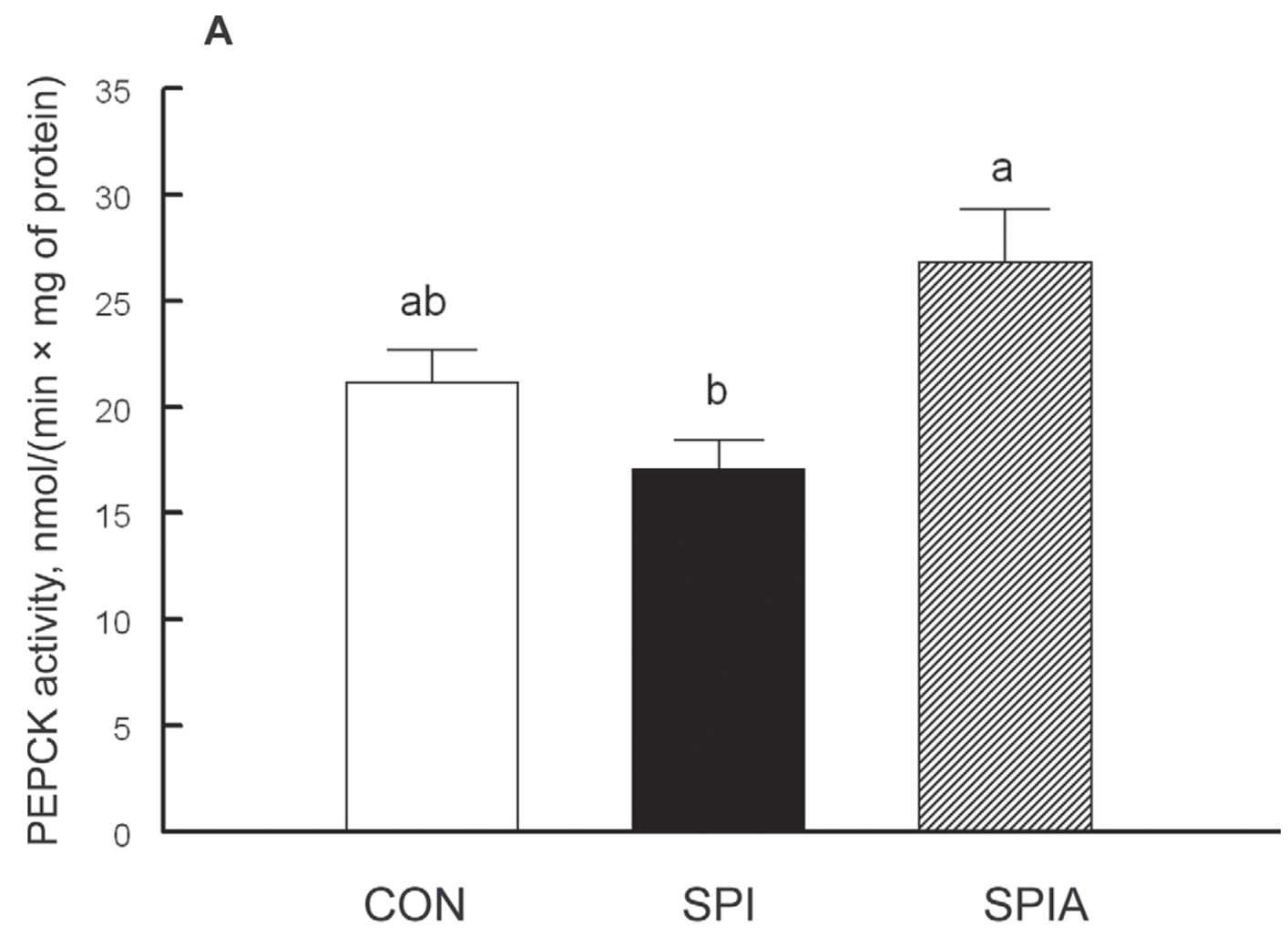

B

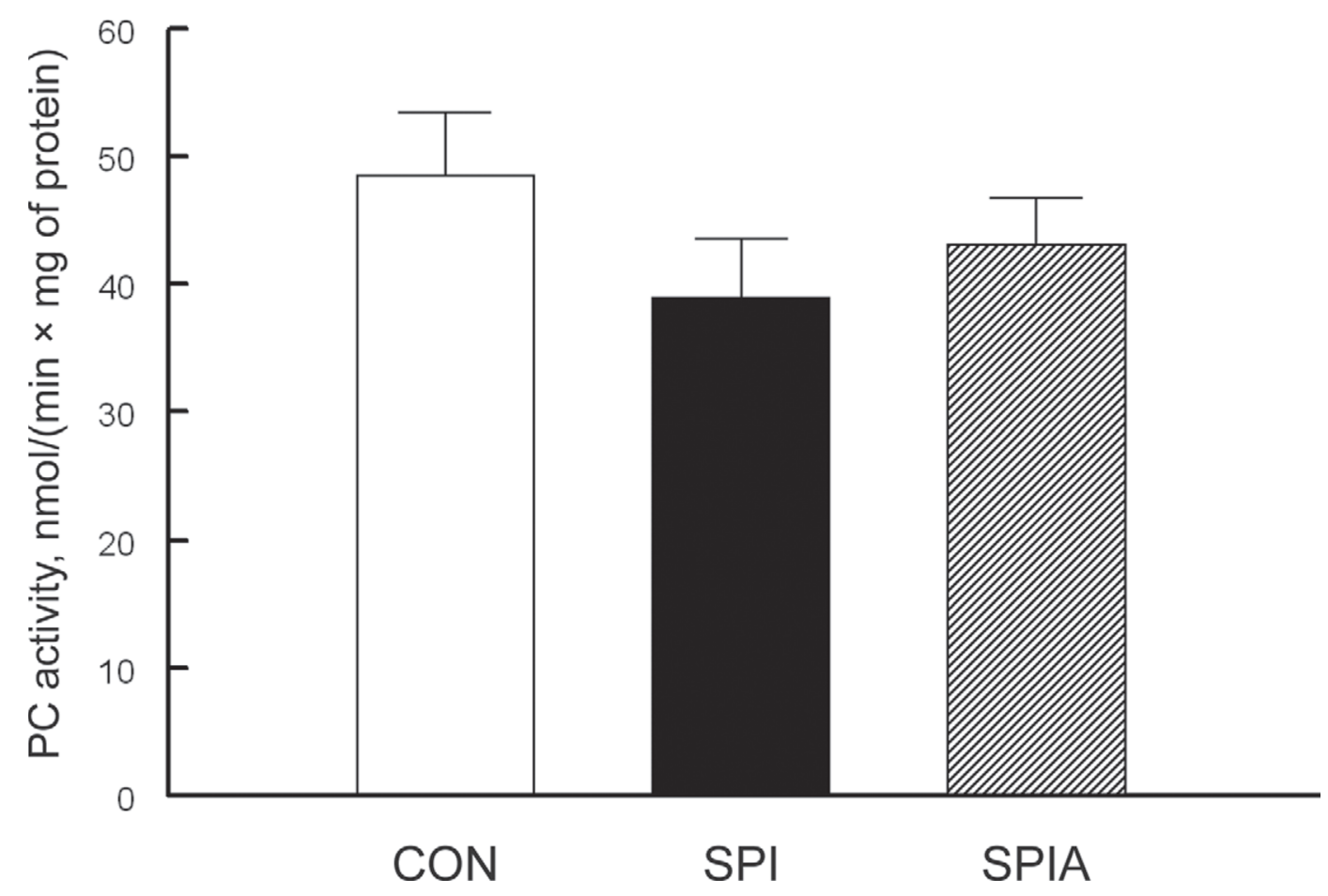

Figure 3. Enzyme activities of hepatic phosphoenolpyruvate carboxykinase (PEPCK; A) and pyruvate carboxylase (PC; B) in goat kids fed milk diets containing CN (control, CON) or soy protein isolate without (SPI) or supplemented with AA (SPIA). Values are means \pm SEM (n $=8$ per group $)$. Analysis of variance $(P$-value $)$ for PEPCK activity: $\operatorname{diet}<0.01$; for PC activity: diet $=0.3$. 
previously identified as being most active in absorption of essential AA (Baumrucker and Davis, 1980), corresponds to the area of high membrane-bound disaccharidase activities. Therefore, AA supplementation to soy protein-based diets may improve carbohydrate digestion in young goats. Because free AA stimulate electrogenic $\mathrm{Na}^{+}$-absorption in the mid and distal part of the porcine small intestine (Grøndahl and Skadhauge, 1997; Boudry et al., 2003), an increased $\mathrm{Na}^{+}$-dependent glucose transport and uptake in the jejunal brush border membrane of SPIA kids could be expected. This is supported by an enhanced maximal glucose transport capacity in SPIA goats (Giere, 2009). Therefore, an increased release of glucose and galactose in mid jejunum could result in a higher intestinal absorption and appearance of glucose in blood circulation (Coombe and Smith, 1973), whereas galactose is preferentially transported to the liver and stored as glycogen (Spedale et al., 1992). The postprandial glucose increase in blood plasma was highest in SPIA goats, but preprandial plasma glucose concentrations did not differ between the SPI and SPIA groups. In addition, oral $\left[{ }^{13} \mathrm{C}_{6}\right]$ glucose uptake was numerically highest in SPIA.

The activities of lactase in the present study were highest in the proximal and lowest in distal jejunum, supporting earlier findings in neonatal calves (Le Huerou et al., 1992). However, maltase activities increased along the intestine in our study with highest activities in the distal jejunum, whereas relatively unchanged activities along the intestine have been reported in lambs (Shirazi-Beechey et al., 1991).

\section{Dietary Effects on Glucose Utilization by the Splanchnic Tissues}

In kids, a milk diet partly containing soy protein instead of $\mathrm{CN}$ decreases villus size and the maximal transport capacity of glucose in the brush border membrane of the jejunum, whereas supplementation of AA to soy protein slightly reverses the impairing effects of soy proteins on villus growth, but leads to an increase in glucose transport capacity (Giere, 2009; Schönhusen et al., 2010a). However, we could not detect a soy-dependent effect on splanchnic FPU of glucose and on glucose oxidation. Our data indicate that the splanchnic tissue uses about one-third of ingested glucose, regardless of whether $\mathrm{CN}$ or soy protein were fed. Likewise, we did not find a dietary effect of CN versus soy protein on glucose oxidation, but in all feeding groups about $50 \%$ of the orally supplied glucose was oxidized to $\mathrm{CO}_{2}$. These data show that the splanchnic tissues extract a significant amount of dietary glucose mainly for oxidative purposes in young goats. van der Schoor et al. (2004) showed that in preterm neonates a similar fraction of the dietary glucose was used in the first pass and that more than $70 \%$ of the glucose turnover is oxidized, whereas in neonatal calves FPU of glucose was much higher and $\mathrm{CO}_{2}$ production from glucose utilization was affected by diet and ontogenetic stage (Steinhoff-Wagner et al., 2011a,b).

Glucose FPU in kids fed SPIA was almost doubled when compared with the SPI diet. However, because of the large interindividual variability in FPU and fFPU, group differences did not become statistically significant. Although great care was taken during performance of the FPU measurements, we cannot exclude that kids responded differently during study performance, which might have led to stressful situations for some of the kids that might have contributed to this great variation within dietary groups. Likewise, plasma appearance rates of orally supplied or i.v. injected labeled glucose remain unaffected by the diet and amounted to about 44 or $77 \mu \mathrm{mol} /(\mathrm{min} \times \mathrm{kg})$. In preterm neonates, van der Schoor et al. (2004) reported similar values for $\mathrm{Ra}_{\mathrm{iv}}$, but using another tracer protocol. Nevertheless, an elevated glucose FPU in SPIA-fed kids may fit to the increased maximal glucose transport capacity in the intestine compared with SP kids (Giere, 2009). Probably, more glucose was utilized in the splanchnic tissue of SPIA- than SPI-fed kids. In neonatal calves, we recently showed an influence of a milk-based formula on glucose FPU (Steinhoff-Wagner et al., 2011a). Therefore, further studies are needed to clarify the effect of protein composition and AA supplementation on glucose FPU in milk-fed preruminants.

\section{Dietary Effects on Systemic and Hepatic Glucose Metabolism}

The plasma glucose status was reduced in soy protein-fed kids and higher basal plasma concentrations of glucose in the CON group were associated with higher basal plasma insulin concentrations in CON kids than in SPI and SPIA kids and higher basal plasma glucagon concentrations in CON kids than in SPIA kids. Although we have not seen significant effects of CN feeding on glucose digestion and FPU, soy protein feeding obviously decreases basal glucose concentrations, and as a consequence, reduces plasma concentrations of insulin, the most important hormone regulating plasma glucose concentrations (Brockman and Laarveld, 1986). Therefore, our data indicate changes in glucose status and endocrine glucose regulation, when soy protein was fed instead of CN. Reasons for this finding are presently unknown. However, although diets were isonitrogenous and isoenergetic, differences in plasma glucose status may result from changes in intestinal glucose absorption as discussed above or differences in 
glucose utilization among feeding groups. In neonatal calves, colostrum compared with formula feeding has marked effects on plasma glucose concentrations and its endocrine regulation. In calves, these findings were related to intestinal glucose absorption (Hammon and Blum, 1998; Steinhoff-Wagner et al., 2011a), but oral glucose uptake was not affected in our study in a significant manner. Although fasted basal plasma glucose concentrations were higher in CON compared with SPIA, plasma glucose concentrations did not differ in the prandial and postprandial state, which suggest no increased glucose absorption in CON goats.

Our data indicate similar activities of hepatic gluconeogenic PC and PEPCK in CON and SPI. In spite of possible differences in the pattern of absorbed AA entering the portal circulation after soy protein or CN feeding (Metges et al., 2000; Daenzer et al., 2001; Bos et al., 2003), the resulting concentration of total free AA appearing in blood plasma of kids did not differ between the SPI and CON groups. However, soy protein feeding caused lower plasma concentrations of gluconeogenic AA, such as Thr and Met, but not of Ala (Schönhusen et al., 2010a,b).

Studies in human subjects showed that supplementation of AA and, thus, the provision of gluconeogenic substrates can increase hepatic glucose production (Tappy et al., 1992). In this context, it is of interest that lowest plasma glucagon concentrations were measured in kids fed SPIA. We have expected a stimulating effect of AA supplementation on glucagon release, because glucagon may support hepatic endogenous glucose production in SPIA goats (Brockman and Laarveld, 1986; Danfær et al., 1995). Indeed, activities of PEPCK were stimulated by AA supplementation in SPIA goats, but this was obviously not mediated by glucagon. Phosphoenolpyruvate carboxykinase is one of the key regulatory enzymes in gluconeogenesis, is related to endogenous glucose production in calves, and is stimulated by glucagon (Donkin, 1999; Steinhoff-Wagner et al., 2011b). In ruminants, however, PEPCK regulation by nutrient factors may be of greater importance, whereas endocrine regulation by glucagon seems to play a minor role (Aschenbach et al., 2010; Steinhoff-Wagner et al., 2011a). Therefore, the elevated PEPCK activities in SPIA goats were probably a result of direct stimulation by AA supplementation. This was not the case for PC activities and PC may be more affected by the glucagon-to-insulin ratio, which was not different among our feeding groups (Donkin, 1999; Aschenbach et al., 2010). From our data, we assume that AA supplementation enhances gluconeogenesis in soy protein-fed goat kids. However, basal plasma glucose concentrations were lower in the SPIA group than in the CON group. Therefore, improved endogenous glucose production in the SPIA group did not result in elevated plasma glucose concentrations in soy protein-fed goats.

The slightly faster increase in plasma triglyceride concentrations after soy feeding might indicate a quicker gastric emptying rate of digesta in SPI kids than in CON kids. During the first hour of digestion, the clotting phenomenon was mostly absent in calves fed milk diets containing 50\% soy protein (Gaudreau and Brisson, 1980). This is in contrast to feeding a milk diet where a large part of $\mathrm{CN}$ and probably also fat was retained in the abomasum to clot (Caugant et al., 1994). We could not find differences in basal concentrations of triglycerides, but plasma NEFA concentrations during the postprandial phase were highest in SPI goats. Higher NEFA concentrations together with lower plasma insulin concentrations (and a numerically greater glucagon:insulin ratio) may point to impaired availability of energy fuels from the diet, although $\mathrm{CN}$ - and soy-based diets were isoenergetic. This finding additionally indicates that energy metabolism may be affected in young goats when diets containing significant amounts of soy proteins were fed to young goats. Although intestinal enzymes and glucose FPU were not involved in impaired nutrient digestion, reduced villus size may be an important factor that was depressed in soy protein-fed kids of this study (Schönhusen et al., 2010a).

\section{CONCLUSIONS}

Feeding milk diets with soy protein isolate seems to affect glucose status and endocrine regulation of plasma glucose in kids, but has no effect on intestinal enzymes involved in carbohydrate digestion, on glucose FPU and glucose oxidation, and on hepatic enzymes involved in gluconeogenesis. The highest activities of lactase and maltase were observed after balancing the AA composition of soy protein by supplementation of AA. Furthermore, AA supplementation leads to increased activities of PEPCK, but reduced plasma glucagon concentrations. Therefore, our findings propose a direct effect of AA supplementation on stimulation of gluconeogenesis, but no effect on plasma glucose concentrations in soy protein-fed young goats.

\section{ACKNOWLEDGMENTS}

The study was supported by Deutsche Forschungsgemeinschaft (Bonn, Germany; DFG SCH 627/1-1). The authors thank S. Kuhla [Leibniz Institute for Farm Animal Biology (FBN), Dummerstorf, Germany] for development of AA supplementation and B. Waischnow, M. Althaus, C. Reiko, I. Brüning, U. Lüdtke, and K. Karpati (FBN) for excellent laboratory work. 


\section{REFERENCES}

Abdul-Razzaq, H. A., and R. Bickerstaffe. 1989. The influence of rumen volatile fatty acids on protein metabolism in growing lambs. Br. J. Nutr. 62:297-310.

Aschenbach, J. R., N. B. Kristensen, S. S. Donkin, H. M. Hammon, and G. B. Penner. 2010. Gluconeogenesis in dairy cows: The secret of making sweet milk from sour dough. IUBMB Life 62:869-877.

Atkin, B. M., M. F. Utter, and M. B. Weinberg. 1979. Pyruvate carboxylase and phosphoenolpyruvate carboxykinase activity in leukocytes and fibroblasts from a patient with pyruvate carboxylase deficiency. Pediatr. Res. 13:38-43.

Barrett, P. H. R., B. M. Bell, C. Cobelli, H. Golde, A. Schumitzky, P. Vicini, and D. M. Forster. 1998. SAAM II: Simulation, analysis, and modeling software for tracer and pharmacokinetic studies. Metabolism 47:484-492.

Baumrucker, C. R., and C. L. Davis. 1980. $\gamma$-Glutamyl transpeptidase activity along the small intestine of sheep: Potential areas of amino acids and peptide transport. J. Dairy Sci. 63:379-384.

Bezabih, M., and E. Pfeffer. 2003. Body chemical composition and efficiency of energy and nutrient utilization by growing preruminant Saanen goat kids. Anim. Sci. 77:155-163.

Bos, C., C. C. Metges, C. Gaudichon, K. J. Petzke, M. E. Pueyo, C. Morens, J. Everwand, R. Benamouzig, and D. Tomé. 2003. Postprandial kinetics of dietary amino acids are the main determinant of their metabolism after soy or milk protein ingestion in humans. J. Nutr. 133:1308-1315.

Boudry, G., J.-P. Lallès, C. H. Malbert, M. L. Grøndahl, M. A. Unmack, and E. Skadhauge. 2003. Soybean impairs $\mathrm{Na}^{+}$-dependent glucose absorption and $\mathrm{Cl}^{-}$secretion in porcine small intestine. Reprod. Nutr. Dev. 43:409-418.

Bradford, M. M. 1976. A rapid and sensitive method for the quantification of microgram quantities of protein utilizing the principle of protein-dye binding. Anal. Biochem. 72:248-254.

Brockman, R. P., and B. Laarveld. 1986. Hormonal regulation of metabolism in ruminants; a review. Livest. Prod. Sci. 14:313-334.

Caugant, I., H. V. Petit, M. Ivan, C. Bard, L. Savoie, R. Toullec, S. Thirouin, and M. Yvon. 1994. In vivo and in vitro gastric emptying of milk replacers containing soybean proteins. J. Dairy Sci. 77:533-540.

Coombe, N. B., and R. H. Smith. 1973. Absorption of glucose and galactose and digestion and absorption of lactose by the preruminant calf. Br. J. Nutr. 30:331-344.

Daenzer, M., K. J. Petzke, B. J. Bequette, and C. C. Metges. 2001. Whole-body nitrogen and splanchnic amino acid metabolism differ in rats fed mixed diets containing casein or its corresponding amino acid mixture. J. Nutr. 131:1965-1972.

Danfær, A., V. Tetens, and N. Agergaard. 1995. Review and an experimental study on the physiological and quantitative aspects of gluconeogenesis in lactating ruminants. Comp. Biochem. Physiol. B Biochem Mol. Biol. 111:201-210.

Degen, G. H., P. Janning, P. Diel, and H. M. Bolt. 2002. Estrogenic isoflavones in rodent diets. Toxicol. Lett. 128:145-157.

Donkin, S. S. 1999. Role of the endocrine pancreas in animal metabolism, growth and performance. Pages 315-328 in Biology of the Pancreas in Growing Animals. S. G. Pierzynowski, and R. Zabielski, ed. Elsevier, Amsterdam, the Netherlands.

Gaudreau, J.-M., and G. J. Brisson. 1980. Abomasum emptying in dairy calves fed milk replacers with varying fat and sources of protein. J. Dairy Sci. 63:426-440.

German Society of Nutrition Physiology. 2003. Ausschuss für Bedarfsnormen der Gesellschaft für Ernährungsphysiologie. No. 9. Empfehlungen zur Energie- und Nährstoffversorgung der Ziegen. DLGVerlag, Frankfurt/Main, Germany.

Giere, J. 2009. Influence of dietary protein source in milk replacers on the function of nutrient transporters in the jejunum of goat kids. Doctoral Diss. Department of Physiology, School of Veterinary Medicine Hannover, Hannover.

Grøndahl, M. L., and M. Skadhauge. 1997. Effect of mucosal amino acids on $\mathrm{SCC}$ and $\mathrm{Na}$ and $\mathrm{Cl}$ fluxes in the porcine small intestine. Comp. Biochem. Physiol. A Physiol. 118:233-237.
Hammon, H. M., and J. W. Blum. 1998. Metabolic and endocrine traits of neonatal calves are influenced by feeding colostrum for different durations or only milk replacer. J. Nutr. 128:624-632.

Hammon, H. M., S. N. Sauter, M. Reist, Y. Zbinden, C. Philipona, C. Morel, and J. W. Blum. 2003. Dexamethasone and colostrum feeding affect hepatic gluconeogenic enzymes differently in neonatal calves. J. Anim. Sci. 81:3095-3106.

Hammon, H. M., G. Stürmer, F. Schneider, A. Tuchscherer, H. Blum, T. Engelhard, A. Genzel, R. Staufenbiel, and W. Kanitz. 2009 Performance and metabolic and endocrine changes with emphasis on glucose metabolism in high-yielding dairy cows with high and low fat content in liver after calving. J. Dairy Sci. 92:1554-1566.

Hennig, U., C. C. Metges, A. Berk, A. Tuchscherer, and M. Kwella. 2004. Relative ileal amino acid flows and microbial counts in intestinal effluents of Goettingen Minipigs and Saddleback pigs are not different. J. Anim. Sci. 82:1976-1985.

Junghans, P., M. Derno, M. Gehre, R. Höfling, P. Kowski, G. Strauch, W. Jentsch, J. Voigt, and U. Hennig. 1997. Colorimetric validation of ${ }^{13} \mathrm{C}$ bicarbonate and doubly labeled water method for determining the energy expenditure in goats. Z. Ernährungswiss. $36: 268-272$.

Junghans, P., S. Görs, I. S. Lang, J. Steinhoff, H. M. Hammon, and C. C. Metges. 2010. A simplified mass isotopomer approach to estimate gluconeogenesis rate in vivo using deuterium oxide. Rapid Commun. Mass Spectrom. 24:1287-1295.

Junghans, P., J. Voigt, W. Jentsch, C. C. Metges, and M. Derno. 2007. The ${ }^{13} \mathrm{C}$ bicarbonate dilution technique to determine energy expenditure in young bulls validated by indirect calorimetry. Livest. Sci. 110:280-287.

Kuhla, S., P. E. Rudolph, D. Albrecht, U. Schönhusen, R. Zitnan, W. Tomek, K. Huber, J. Voigt, and C. C. Metges. 2007. A milk diet partly containing soy protein does not change growth but regulates jejunal proteins in young goats. J. Dairy Sci. 90:4334-4345.

Lalles, J. P., R. Toullec, P. Branco Pardal, and J. W. Sissons. 1995. Hydrolyzed soy protein isolate sustains high nutritional performance in veal calves. J. Dairy Sci. 78:194-204.

Langman, J. M., and R. Rowland. 1990. Activity of duodenal disaccharidases in relation to normal and abnormal mucosa morphology. J. Clin. Pathol. 43:537-540.

Le Huerou, I., P. Guilloteau, C. Wicker, A. Mouats, J.-A. Chayvialle, C. Bernard, J. Burton, R. Toullec, and A. Puigserver. 1992. Activity distribution of seven digestive enzymes along the small intestine in calves during development and weaning. Dig. Dis. Sci. 37:40-46.

Mabjeesh, S. J., D. Guy, and D. Sklan. 2003. Na ${ }^{+} /$glucose co-transporter abundance and activity in the small intestine of lambs: Enhancement of abomasal infusion of casein. Br. J. Nutr. 89:573580

Metges, C. C., A. E. El-Khoury, A. B. Selvaraj, R. H. Tsay, A. Atkinson, M. M. Regan, B. J. Bequette, and V. R. Young. 2000. Kinetics of $\mathrm{L}-\left[1-{ }^{13} \mathrm{C}\right]$ leucine when ingested with free amino acids, unlabeled or intrinsically labeled casein. Am. J. Physiol. Endocrinol. Metab. 278:E1000-E1009.

Mir, P. S., D. R. C. Bailey, Z. Mir, S. D. Morgan Jones, H. Douwes, T A. McAllister, R. J. Weselake, and F. J. Lozeman. 1997. Activity of intestinal mucosal membrane carbohydrases in cattle of different breeds. Can. J. Anim. Sci. 77:441-446.

Montagne, L., R. Toullec, T. Savidge, and L. P. Lallès. 1999. Morphology and enzyme activities of the small intestine are modulated by the dietary protein source in the preruminant calf. Reprod. Nutr. Dev. 39:455-466.

Naumann, C., and R. Bassler. 1993. Analytical Methods III. The Chemical Analysis of Feed. VDLUFA-Press, Darmstadt, Germany.

Ontsouka, E. C., B. Korczak, H. M. Hammon, and W. J. Blum. 2004. Real-time PCR quantification of bovine lactase mRNA: Localization in the gastrointestinal tract of milk-fed calves. J. Dairy Sci. 87:4230-4237.

Pfaffenberger, C. D., J. Szafranek, M. G. Horning, and E. C. Horning. 1975. Gas chromatographic determination of polyols and aldoses in human urine as polyacetates and aldononitrile polyacetates. Anal. Biochem. 63:501-512. 
SAS Institute. 2004. SAS/STAT ${ }^{\circledR} 9.1$ User's Guide. SAS Institute Inc., Cary, NC.

Schönhusen, U., A. Flöter, P. Junghans, E. Albrecht, K.-J. Petzke, R. Zitnan, P. Guilloteau, C. C. Metges, and H. M. Hammon. 2010a. Morphology, proliferation, and ribonucleic acid and fractional protein syntheses in the small intestinal mucosa of young goats fed soy protein-based diets with or without amino acid supplementation. J. Dairy Sci. 93:4165-4179.

Schönhusen, U., S. Kuhla, P. E. Rudolph, R. Zitnan, D. Albrecht, K Huber, J. Voigt, A. Flöter, H. M. Hammon, and C. C. Metges. 2010b. Alterations in the jejunum of young goats caused by feeding soy-protein based diets. J. Anim. Physiol. Anim. Nutr. (Berl.) 94:1-14.

Seegraber, F. J., and J. L. Morrill. 1986. Effect of protein source in calf milk replacers on morphology and absorptive ability of small intestine. J. Dairy Sci. 69:460-469.

Shirazi-Beechey, S. P., B. A. Hirayama, Y. Wang, D. Scott, M. W. Smith, and E. M. Wright. 1991. Ontogenetic development of lamb intestinal sodium-glucose co-transporter is regulated by diet. J. Physiol. 437:699-708.

Spedale, S. B., F. C. Battaglia, and J. W. Sparks. 1992. Hepatic metabolism of glucose, galactose, and lactate after milk feeding in newborn lambs. Am. J. Physiol. 262:E46-E51.

Steinhoff-Wagner, J., S. Görs, P. Junghans, R. M. Bruckmeier, E. Kanitz, C. C. Metges, and H. M. Hammon. 2011a. Intestinal glucose absorption but not endogenous glucose production differs between colostrum- and formula-fed neonatal calves. J. Nutr. 141:48-55.

Steinhoff-Wagner, J., S. Görs, P. Junghans, R. M. Bruckmeier, E. Kanitz, C. C. Metges, and H. M. Hammon. 2011b. Maturation of endogenous glucose production in preterm and term calves. J. Dairy Sci. 94:5111-5123.

Tappy, L., K. Acheson, S. Normand, D. Schneeberger, A. Thélin, C Pachiaudi, J. P. Riou, and E. Jéquier. 1992. Effects of infused amino acids on glucose production and utilization in healthy human subjects. Am. J. Physiol. 262:E826-E833.

Tivey, D. R., and M. W. Smith. 1989. Cytochemical analysis of single villus peptidase activities in pig intestine during neonatal development. Histochem. J. 21:601-608.

van der Schoor, S. R. D., B. Stoll, D. L. Wattimena, H. A. Büller, D. Tibboel, D. G. Burrin, and J. B. van Goudoever. 2004. Splanchnic bed metabolism of glucose in preterm neonates. Am. J. Clin. Nutr. 79:831-837.

van der Schoor, S. R., J. B. van Goudoever, B. Stoll, J. F. Henry, J. R. Rosenberger, D. G. Burrin, and P. J. Reeds. 2001. The pattern of intestinal substrate oxidation is altered by protein restriction in pigs. Gastroenterology 121:1167-1175.

Windmueller, H. G., and A. E. Spaeth. 1980. Respiratory fuels and nitrogen metabolism in vivo in small intestine of fed rats. Quantitative importance of glutamine, glutamate, and aspartate. J. Biol Chem. 255:107-112. 